\title{
Clusters as ligands: Synthesis, structure and coordination chemistry of ruthenium clusters derived from 4- and 5-ethynyl-2,2'-bipyridine $\dagger$
}

Sören Bock, ${ }^{\mathrm{a}}$ Campbell F. Mackenzie, ${ }^{\mathrm{a}}$ Brian W. Skelton, ${ }^{\mathrm{b}}$ Lindsay T. Byrne, George A. Koutsantonis, ${ }^{\mathrm{a} *}$ Paul J. Low ${ }^{\mathrm{a} *}$

${ }^{a}$ School of Chemistry and Biochemistry, University of Western Australia, Crawley, Western Australia 6009, Australia

${ }^{b}$ Centre for Microscopy, Characterisation and Analysis, University of Western Australia, Crawley, Western Australia 6009, Australia

\section{Abstract}

The reaction of $\left[\mathrm{Ru}_{3}(\mathrm{CO})_{10}(\mu\right.$-dppm) $](\mathbf{1})$ with 4-ethynyl-2,2'-bipyridine (2) or 5ethynyl-2,2'-bipyridine (3) affords the $\mathrm{Ru}_{3} \mathrm{C}_{2}$ clusters $\left[\mathrm{Ru}_{3}(\mu-\mathrm{H})\left(\mu_{3}\right.\right.$ $\left.\left.\mathrm{C}_{2} \mathrm{bpy}\right)(\mathrm{CO})_{7}(\mathrm{dppm})\right](\mathrm{bpy}=4$-bpy, 4 (22\%); bpy = 5-bpy, 5(55\%)). Complexes 4 and 5 have been fully characterised by NMR spectroscopy, with 2D-COSY methods being used to aid ${ }^{1} \mathrm{H}$ NMR assignments, and single crystal X-ray diffraction. The pendant bipyridyl moiety presents as a site for further reaction using the 'Tinkertoy' approach, and subsequent reactions of 4 and 5 with $\mathrm{PdCl}_{2}(\mathrm{NCPh})_{2}$ affords the bimetallic complexes $\left[\mathrm{Ru}_{3}(\mu-\mathrm{H})\left\{\mu_{3}-\mathrm{C}_{2}\right.\right.$ bpy $\left.\left.\left(\kappa^{2}-N^{\prime}, N-\mathrm{PdCl}_{2}\right)\right\}(\mathrm{CO})_{7}(\mathrm{dppm})\right]$ bpy = 4-bpy, $6(55 \%)$; bpy $=5-b p y, 7(35 \%))$.

$\uparrow$ Dedicated to memory of Professor Lord Sir Jack Lewis, FRS, a true organometallic pioneer. 


\section{Introduction}

The development of transition metal cluster chemistry owes much to the curiosity driven endeavours and synthetic prowess of the early pioneers of organometallic chemistry [1-4]. The reactions of the group 8 trimetallic dodecacarbonyl clusters $\left(\mathrm{M}_{3}(\mathrm{CO})_{12}, \mathrm{M}=\mathrm{Fe}(\mathbf{1 - F e}), \mathrm{Ru}(\mathbf{1}-\mathbf{R u})\right.$, Os $\left.(\mathbf{1 - O s})\right)$, which are readily obtained in high yields from simple reactions and offer opportunity to explore trends down the group, have proved to be particularly useful scaffolds upon which to explore metal framework rearrangements, growth and fragmentation processes, ligand exchange and coupling reactions, cluster dynamics and so on [5].

Given the state of knowledge of the cluster reactions with an immense array of different functional groups that has been accumulated over the last 5 or so decades, it is interesting to consider cluster-ligand combinations as construction units within the 'Tinkertoy' approach to the design of novel molecular structures $[6,7]$. This approach requires the careful selection of orthogonal reactions to sequentially introduce metal centres and ligands to a growing molecular, cluster-based scaffold (which might be described here in terms of the "clusters as ligands" concept [8]).

The Tinkertoy approach to molecular design and synthesis requires the linking of metal-complex 'nodes' by various bi-functional ligands. Selective synthetic design requires the use of both mono-functionalised fragments to cap or block the growing molecular structure, and bi- (or higher multi) functional fragments to serve as connectors that link the growing structure with incoming building blocks. We have recently become interested in the organometallic chemistry of ethynyl-substituted 
heterocycles $[9,10]$, including 5-ethynyl-2,2'-bipyridine [11]. The bi-functional nature of these compounds makes them ideally suited for the construction of multimetallic systems, and 5-ethynyl-2,2'-bipyridine has found application as a linking unit within the Tinkertoy-based construction of multi-metallic frameworks based on monomolecular nodes $[12,13]$. Further exploration has revealed the capacity of such ligands to promote weak electronic interactions between the tethered nodes [14].

The cluster chemistry of alkynes has been particularly well explored for the group 8 metals, with demonstrated capacity to serve as a terminal end-on, 1 -e donor $\eta^{1}-\mathrm{C} \equiv \mathrm{CR}$ fragment, 3-e donor $\mu-\mathrm{C}_{2} \mathrm{R}$ fragment bridging a metal-metal bond or edge, a 4-e donor face capping alkyne $\mu-\mathrm{RC}_{2} \mathrm{R}$ ', 5-e donor $\mu-\mathrm{C}_{2} \mathrm{R}$ fragment or even a 6-e donor $\mathrm{C}_{2-}$ fragment. The chemistry of cluster-bound alkynes, acetylides and related all-carbon fragments has been reviewed in a wide variety of contexts [15-20]. In contrast, literature concerning the course of reactions between group 8 clusters and 2,2'bipyridine derivatives is rather more sparse, as described below.

The initial investigations in the area of group 8 clusters with 2,2-bipyridine (bpy) were undertaken by the Lewis group, with reaction of 2,2'-bipyridine and $\left[\mathrm{Ru}_{3}(\mathrm{CO})_{10}(\mathrm{NCMe})_{2}\right]$ affording $\left[\mathrm{Ru}_{3}(\mathrm{CO})_{10}\left(\mu-N, N^{\prime}-\mathrm{bpy}\right)\right]$, and subsequent thermolysis resulting in ortho-metallation of the heterocycle to give $\left[\operatorname{Ru}_{3}(\mu-\mathrm{H})\left(\mu-\left\{\kappa^{2}-N, C-\eta^{1}-N^{\prime}-\right.\right.\right.$ $\left.\left.\mathrm{C}_{10} \mathrm{H}_{7} \mathrm{~N}_{2}\right\}\right)(\mathrm{CO})_{9}$ ] [21], the structure of the Os analogue having been determined [22]. From $\left[\mathrm{Ru}_{3}(\mathrm{CO})_{12}\right]$ and bpy, crystallographically characterised $\left[\mathrm{Ru}_{3}(\mu-\mathrm{CO})_{2}\left(\kappa^{2}-N^{\prime}, N-\right.\right.$ bpy $(\mathrm{CO})_{8}$ ] with an $\mathrm{Fe}_{3}(\mathrm{CO})_{12}$-like structure was obtained [23-25]: thermolysis afforded the ortho-metallated product [24]. Unsurprisingly given the weaker Fe-Fe bonds, trimethylamine- $N$-oxide promoted reactions of $\left[\mathrm{Fe}_{3}(\mathrm{CO})_{12}\right]$ and $\left[\mathrm{Fe}_{2}(\mathrm{CO})_{9}\right]$ 
with bpy gave mono- $\left[\mathrm{Fe}(\mathrm{CO})_{3}(\mathrm{bpy})\right]$ and bi-metallic $\left[\mathrm{Fe}_{2}\left(\kappa^{2}-N^{\prime}, N\right.\right.$-bpy $\left.)\left(\mathrm{CO}_{7}\right)\right]$ products [25]. Similarly, whilst the higher nuclearity cluster $\left[\mathrm{Fe}_{5}\left(\mu_{5}-\mathrm{C}\right)(\mathrm{CO})_{15}\right]$ fragments into $\left[\mathrm{Fe}(\text { bpy })_{3}\right]\left[\mathrm{Fe}_{4}(\mu-\mathrm{H})\left(\mu_{4}-\mathrm{C}\right)(\mathrm{CO})_{12}\right]_{2}$ on reaction with bpy [25], carbonyl substitution and ortho-metallation processes are observed in analogous reaction with higher nuclearity Ru clusters $\left[\mathrm{Ru}_{4}(\mu-\mathrm{H})_{4}(\mathrm{CO})_{12}\right][26]$ and $\left[\mathrm{Ru}_{5}\left(\mu_{5}-\mathrm{C}\right)(\mathrm{CO})_{15}\right][27]$, although $\left[\mathrm{Ru}_{6}\left(\mu_{6}-\mathrm{C}\right)(\mathrm{CO})_{17}\right]$ proved rather more prone to cluster fragmentation in the presence of bpy [27]. Interestingly, the methyl C-H bonds in 6,6'-dimethyl-2,2'bipyridine are readily activated on reaction with $\left[\mathrm{Ru}_{3}(\mathrm{CO})_{12}\right]$ or $\left[\mathrm{Os}_{3}(\mathrm{CO})_{10}(\mathrm{NCMe})_{2}\right]$ to give products containing methylene $\left(\mathrm{CH}_{2}\right)$, methyne $(\mathrm{CH})$ and carbyne $(\mathrm{C})$ clusters [28-30].

In the spirit of the early pioneers in the field, we were therefore prompted to consider the reactions of the prototypical clusters $\left[\mathrm{Ru}_{3}(\mathrm{CO})_{12}\right]$ and $\left[\mathrm{Ru}_{3}(\mathrm{CO})_{10}(\mathrm{dppm})\right]$ with 4and 5-ethynyl-2,2'-bipyridine, both to explore the competitive reactivity of the acetylene and bipyridine in the same ligand towards the metal framework, and also as a potential route to the assembly of larger structures via Tinkertoy concepts.

\section{Results and Discussion}

\subsection{Synthesis}

Survey reactions of $\left[\mathrm{Ru}_{3}(\mathrm{CO})_{12}\right](\mathbf{1}-\mathbf{R u})$ with 4- and 5-ethynyl-2,2'-bipyridine $(\mathbf{2}, \mathbf{3})$ were conducted in hexane and monitored by TLC and IR spectroscopy. In contrast to reactions between $\mathbf{1}-\mathrm{Ru}$ and $\mathrm{Me}_{3} \mathrm{SiC} \equiv \mathrm{CC} \equiv \mathrm{CC} \equiv \mathrm{CSiMe}_{3}$ carried out in this fashion, which affords the tetrametallic cluster $\left[\mathrm{Ru}_{4}(\mathrm{CO})_{12}\left(\mu-\mathrm{Me}_{3} \mathrm{SiC} \equiv \mathrm{CC}_{2} \mathrm{C} \equiv \mathrm{CSiMe}_{3}\right)\right](35 \%)$ as the major product [31], these survey reactions gave a plethora of products, none of 
which could be satisfactorily isolated or characterised. Similar difficulties were encountered in thermal reactions between 1-Ru and $\mathbf{2}$ or $\mathbf{3}$ in THF. Although activation of 1-Ru towards reactions with alkynes under mild conditions through reaction with trimethylamine- $N$-oxide (TMNO) is well known [32-34], unfortunately here reactions conducted in the presence of trimethylamine $N$-oxide (TMNO) also failed to yield tractable products. In seeking other methods of mild activation of the cluster core towards $\mathbf{2}$ and $\mathbf{3}$ we turned to a fluoride ion catalyst $[35,36]$, but with similarly singular lack of success.

In contrast to the often capricious reactions of terminal alkynes with 1-Ru, the dppmsubstituted cluster $\left[\mathrm{Ru}_{3}(\mathrm{CO})_{10}(\mathrm{dppm})\right]$ undergoes rather facile thermal reaction with terminal alkynes, $\mathrm{HC} \equiv \mathrm{CR}$, to give clusters of general type $\mathrm{Ru}_{3}(\mu-\mathrm{H})(\mu-$ $\left.\mathrm{C}_{2} \mathrm{R}\right)(\mathrm{CO})_{7}(\mathrm{dppm})$ [37]. Gratifyingly, reactions of both $\mathbf{2}$ and $\mathbf{3}$ with $\left[\mathrm{Ru}_{3}(\mathrm{CO})_{10}(\mathrm{dppm})\right]$ gave the anticipated bipyridine-substituted $\mathrm{Ru}_{3} \mathrm{C}_{2}$ clusters 4 $(22 \%)$ and 5 (55\%) (Scheme 1). Each cluster displayed the usual v(CO) pattern associated with the $\left[\mathrm{Ru}_{3}(\mu-\mathrm{H})\left(\mu-\mathrm{C}_{2} \mathrm{R}\right)(\mathrm{CO})_{7}(\mathrm{dppm})\right]$ framework (c.f. $\left[\mathrm{Ru}_{3}(\mu-\mathrm{H})(\mu-\right.$ $\left.\left.\mathrm{C}_{2} \mathrm{Ph}\right)(\mathrm{CO})_{7}(\mathrm{dppm})\right]$ v(CO) (cyclohexane): 2065s, 2011vs, 2003vs, 1994sh, 1985m, $1958 \mathrm{~m}, 1940 \mathrm{w} \mathrm{cm}^{-1}$ ) [37], in addition to characteristic ${ }^{31} \mathrm{P}$ NMR spectra containing $\operatorname{doublet}\left(J_{\mathrm{PP}}=52 \mathrm{~Hz}\right)$ and doublet of doublet $\left(J_{\mathrm{PP}}=52 \mathrm{~Hz} ; J_{\mathrm{PH}}=27 \mathrm{~Hz}\right)$ signals evincing the localisation of the hydride $\left(\delta_{\mathrm{H}} \mathrm{ca}-19 \mathrm{ppm}\right)$ on the NMR time scale (the hydride falling out of the range of the proton decoupler). Positive ion electrospray ionisation mass spectra (ES-MS) of $\mathbf{4}$ and $\mathbf{5}$ were characterised by the observation of the $[\mathrm{M}+\mathrm{H}]^{+}$and $[\mathrm{M}+\mathrm{Na}+\mathrm{NCMe}]^{+}$ions $[38]$. 


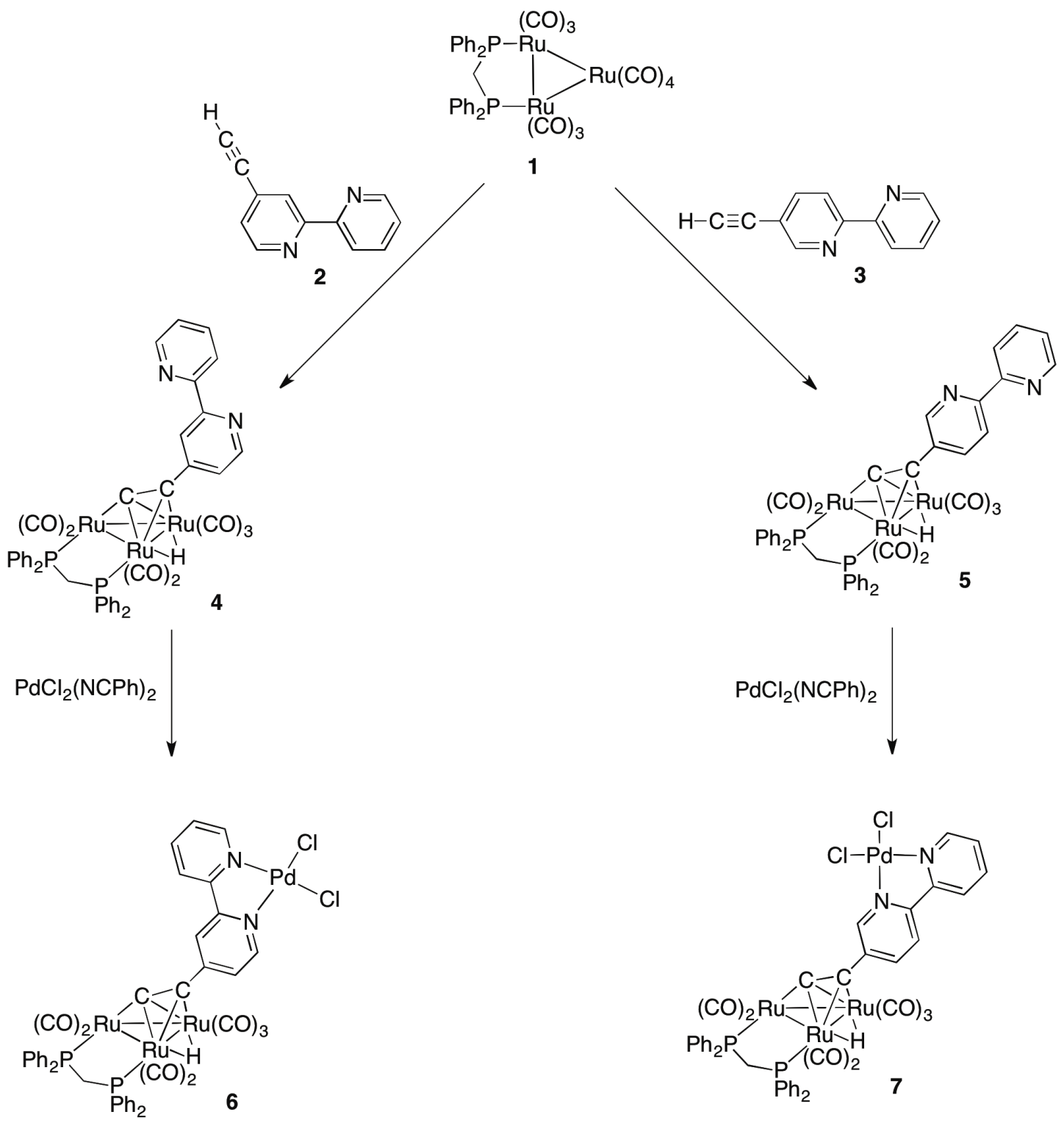

Scheme 1. The preparation of compounds 4, 5, 6 and 7.

The clusters 4 and 5 were analysed by ${ }^{1} \mathrm{H}$ and ${ }^{31} \mathrm{P}\left\{{ }^{1} \mathrm{H}\right\}$ NMR spectroscopies, with ${ }^{1} \mathrm{H}$ resonances assigned through the application of ${ }^{1} \mathrm{H}-{ }^{1} \mathrm{H}$ COSY methods, and elemental analysis. The atom labelling scheme used in the NMR discussions follows the conventional numbering of the 2,2 '-bipyridine fragment. Whilst ${ }^{1} \mathrm{H}-{ }^{1} \mathrm{H}$ correlations allowed the protons of each $\mathrm{C}_{6} \mathrm{H}_{5}$ ring of the dppm ligands to be associated, it was not possible to definitively determine the identity of each ring. These ring systems are therefore arbitrarily labelled A, B, C and D in Experimental, Section 4.2. 
The signals in the ${ }^{1} \mathrm{H}-\mathrm{NMR}$ spectra of $\mathbf{4}$ and $\mathbf{5}$ could be assigned by using 2D-NMR spectroscopy, specifically ${ }^{1} \mathrm{H}-{ }^{1} \mathrm{H}-\mathrm{COSY}$ methods. Assignments are given here within a first order approximation of the coupling interactions. In the case of compound 4 , the hydrogen atoms in the 6- and 6' positions of the bipyridyl fragment $\left(\mathrm{H}^{6}\right.$ and $\left.\mathrm{H}^{6}\right)$ appear at the highest chemical shifts ( 8.46 and $8.74 \mathrm{ppm}$, respectively), due to their proximity to the nitrogen atoms, and were therefore readily identified and assigned. From there on, following the coupling interactions and cross-peaks the resonances arising from the hydrogen atoms in 5- and 5'- positions could be identified $\left(\mathrm{H}^{5}, 7.16\right.$ ppm; $\mathrm{H}^{5}$ coincident with resonances from one of the dppm phenyl rings near 7.35 ppm). The $\mathrm{H}^{5}$ and $\mathrm{H}^{6}$-protons appear as doublets displaying a mutual coupling of ${ }^{3} J_{\mathrm{HH}}$ $=5 \mathrm{~Hz}$, with the resonance for $\mathrm{H}^{5}$ being somewhat broadened by additional ${ }^{4} J_{\mathrm{HH}}$ to $\mathrm{H}^{3}$, which is also found as a somewhat broadened resonance at $8.16 \mathrm{ppm}$. The $\mathrm{H}^{5}$ shows further cross-peaks identifying $\mathrm{H}^{4}$, which appears as a doublet of doublets, being also coupled to $\mathrm{H}^{3}$. However, the ${ }^{3} J_{\mathrm{HH}^{-}}$-coupling constants between $\mathrm{H}^{4}$ and both $\mathrm{H}^{3}$ and $\mathrm{H}^{5^{\prime}}$ are identical making the signal to appear as a pseudo-triplet at $7.82 \mathrm{ppm}$. The $\mathrm{H}^{3}$ proton could easily be assigned to a doublet at $8.33 \mathrm{ppm}$.

The ${ }^{1} \mathrm{H}$ NMR spectrum of compound 5 was assigned in similar fashion with $\mathrm{H}^{6}$ (8.46 ppm) and $\mathrm{H}^{6^{\prime}}(8.69 \mathrm{ppm})$ again being used to commence the assignment based on the COSY spectrum. From $\mathrm{H}^{6}$, signals $\mathrm{H}^{3}, \mathrm{H}^{4^{\prime}}$ and $\mathrm{H}^{5^{\prime}}$ could be assigned from following the coupling interactions along the ring, starting with $\mathrm{H}^{5}$ due to the coupling interaction with $\mathrm{H}^{6}$ ' with a ${ }^{3} J$-coupling constant of $4.8 \mathrm{~Hz}$. The signal at $7.31 \mathrm{ppm}$ arising from $\mathrm{H}^{5}$ shows a doublet of doublets due to the additional coupling with $\mathrm{H}^{4}$ $\left({ }^{3} J\right.$-coupling constant of $\left.7.7 \mathrm{~Hz}\right)$. This interaction allowed the assignment of the signal 
at $7.82 \mathrm{ppm}$ to $\mathrm{H}^{4^{\prime}}$. The signal appears as pseudo-triplet due to the equal ${ }^{3} J_{\mathrm{HH}^{-}}$ coupling constants of $\mathrm{H}^{4}$ with $\mathrm{H}^{3}$ and $\mathrm{H}^{5}$ of $7.7 \mathrm{~Hz}$ in each case. Following this last coupling along the ring the doublet at $8.37 \mathrm{ppm}$ could be assigned to $\mathrm{H}^{3}$. This leaves two doublets (in first order approximation) in the aromatic region, each integrating to $1 \mathrm{H}$, to be assigned to $\mathrm{H}^{3}$ and $\mathrm{H}^{4}$. These doublets show a mutual ${ }^{3} J$-coupling constant of $8.2 \mathrm{~Hz}$. However, the doublet at $7.66 \mathrm{ppm}$ shows broadening due to additional coupling to $\mathrm{H}^{6}$, allowing the assignment of this signal to $\mathrm{H}^{4}$. The remaining doublet at $8.21 \mathrm{ppm}$ can therefore be assigned to $\mathrm{H}^{3}$.

The presence of the 4- and 5- substituted bipyridyl moieties in clusters $\mathbf{4}$ and $\mathbf{5}$ provides opportunity to tether the cluster core to other metal centres. Here, this property was examined briefly through reaction with $\mathrm{PdCl}_{2}(\mathrm{NCPh})_{2}$. Coordination of the $\mathrm{PdCl}_{2}$ fragment to the clusters $\mathbf{4}$ and $\mathbf{5}$ occurred readily, and was complete (as adjudged by TLC and IR spectroscopy) within 5 minutes at room temperature in THF solution, and the orange coloured, heterometallic products 6 and 7 isolated and purified by precipitation and crystallisation (Scheme 1).

The ${ }^{1} \mathrm{H}$ and ${ }^{31} \mathrm{P}\left\{{ }^{1} \mathrm{H}\right\}$ NMR and IR (v(CO)) spectra of compounds 6 and 7 were, as might be expected, similar to those of the precursor clusters 4 and $\mathbf{5}$, although the lower solubility of the heterometallic species precluded closer examination and recording of the ${ }^{13} \mathrm{C}$ NMR spectra. The most diagnostic spectroscopic changes associated with coordination of the $\left\{\mathrm{PdCl}_{2}\right\}$ fragment were the small shift of the $v(\mathrm{CO})$ bands in the infrared spectra to higher energies, the shift to lower field of the signals arising from $\mathrm{H}^{6}$ and $\mathrm{H}^{6}$ in the ${ }^{1} \mathrm{H}-\mathrm{NMR}$ spectrum and the colour change from yellow to orange associated with $\mathrm{Pd} \rightarrow$ bpy MLCT transitions in 6 and 7 . Whilst the low solubility of the heterometallic complexes 6 and 7 complicated solution 
spectroscopy, 1-D ${ }^{1} \mathrm{H}$ NMR and $2 \mathrm{D}{ }^{1} \mathrm{H}-{ }^{1} \mathrm{H}-\mathrm{COSY}$ NMR spectra of sufficient quality were obtained to permit assignment of the bipyridyl signals based on comparison with the spectra of the parent clusters $\mathbf{4}$ and $\mathbf{5}$.

The ${ }^{1} \mathrm{H}-\mathrm{NMR}$ spectrum of compound $\mathbf{6}$ allowed the assignment of the signals at $9.49 \mathrm{ppm}$ and $8.81 \mathrm{ppm}$ to $\mathrm{H}^{6}$ and $\mathrm{H}^{6}$ respectively. Comparing the coupling constant of the doublet due to $\mathrm{H}^{6}$ of $6.0 \mathrm{~Hz}$ to the coupling constants of the other doublets in the spectrum, the signal at $6.96 \mathrm{ppm}$, further split by coupling to $\mathrm{H}^{3}$, could be assigned to $\mathrm{H}^{5}$. The doublet at $7.73 \mathrm{ppm}$ with the integral count of $1 \mathrm{H}$ and a coupling constant of $7.8 \mathrm{~Hz}$ was assigned to $\mathrm{H}^{3}$ since both $\mathrm{H}^{4}$ and $\mathrm{H}^{5^{\prime}}$ are expected to display additional coupling. Comparing the splitting pattern of the signals of $\mathrm{H}^{4}$ and $\mathrm{H}^{5}$ to the parent compound 4 the signal for $\mathrm{H}^{4}$ is expected to show two very similar coupling constants from the coupling interactions with $\mathrm{H}^{3}$ and $\mathrm{H}^{5}$ ' contrary to the significantly different coupling constants for $\mathrm{H}^{5}$. Therefore the signal of $\mathrm{H}^{4}$ could, as already observed for compound 4, appear as a pseudo-triplet instead of the expected doublet of doublets. This is consistent with the signal at $8.09 \mathrm{ppm}$ that appears as a pseudotriplet with a coupling constant of $7.8 \mathrm{~Hz}$, matching the ${ }^{3} J$-coupling constant of $\mathrm{H}^{3}$ and therefore was assigned to $\mathrm{H}^{4}$. The doublet of doublets at $7.00 \mathrm{ppm}$ can be assigned to $\mathrm{H}^{5}$ showing matching coupling constants of $7.8 \mathrm{~Hz}$ and $5.7 \mathrm{~Hz}$ respectively. The signal for the remaining $\mathrm{H}^{3}$ could only be assigned by COSY spectroscopy to the region around $7.55 \mathrm{ppm}$, being superimposed with the phenyl proton signals.

For compound 7, again, $\mathrm{H}^{6}$ and $\mathrm{H}^{6}$ could be assigned in the ${ }^{1} \mathrm{H}-\mathrm{NMR}$ spectrum due to their low field shift. The doublet at $9.49 \mathrm{ppm}$ with a coupling constant of $5.6 \mathrm{~Hz}$ could 
be assigned to $\mathrm{H}^{6}$ and the doublet at $8.85 \mathrm{ppm}$ with a coupling constant of $1.6 \mathrm{~Hz}$, probably due to coupling with $\mathrm{H}^{4}$, could be assigned to $\mathrm{H}^{6}$. Following the coupling interactions $\mathrm{H}^{5}$ could be assigned to the region near $7.57 \mathrm{ppm}$, although the exact position cannot be determined due to superposition of the signal with a signal from a phenyl ring. However, $\mathrm{H}^{4}$ could be assigned to the pseudo-triplet at $8.09 \mathrm{ppm}$ with a coupling constant of $7.6 \mathrm{~Hz}$ for the coupling with $\mathrm{H}^{5^{\prime}}$ and $\mathrm{H}^{3^{\prime}}$, both. The doublet at $7.89 \mathrm{ppm}$ with a coupling constant of $7.6 \mathrm{~Hz}$ could then be assigned to $\mathrm{H}^{3}$. The remaining $\mathrm{H}^{3}$ and $\mathrm{H}^{4}$ should both appear as doublet resonances. A pseudo-doublet at $7.86 \mathrm{ppm}$, somewhat broadened due to coupling with $\mathrm{H}^{6}$, could be assigned to $\mathrm{H}^{4}$. The signal for $\mathrm{H}^{3}$ was assigned to a resonance near $7.76 \mathrm{ppm}$ by COSY spectroscopy, although this resonance was heavily obscured by phenyl signals.

The ES-MS of the heterometallic complexes were characterised by ions assigned to $[\mathrm{M}+\mathrm{MeCN}]^{+}$and $[\mathrm{M}+\mathrm{H}+\mathrm{Na}+\mathrm{MeCN}]^{+}$, with evidence of higher mass aggregates involving solvent, alkali metal ions and $\left\{\mathrm{PdCl}_{2}\right\}_{\text {n }}$ polymers. Whilst compound 6 analysed well for a $\mathrm{MeOH} / \mathrm{CH}_{2} \mathrm{Cl}_{2}$ solvate (these solvents being used in the recrystallization of the bulk sample), all efforts to obtain a satisfactory analysis of 7 failed, likely due to complications with partial desolvation.

\subsection{Molecular structures}

Crystals of each of 4 (from $\left.\mathrm{CH}_{2} \mathrm{Cl}_{2} / \mathrm{MeOH}\right), \mathbf{5}\left(\mathrm{CH}_{2} \mathrm{Cl}_{2} / \mathrm{MeOH}\right), \mathbf{6}$ (as a $\mathrm{MeOH} /$ $\mathrm{CHCl}_{3}$ solvate from those solvents) and 7 (as a bis- $\mathrm{CH}_{2} \mathrm{Cl}_{2}$ solvate from $\mathrm{CH}_{2} \mathrm{Cl}_{2}$ / hexanes) were confirmed by single crystal X-ray diffraction. Plots of each molecule are given in Figures $1-4$, and a summary of important bond lengths and angles is given in Table 1. 


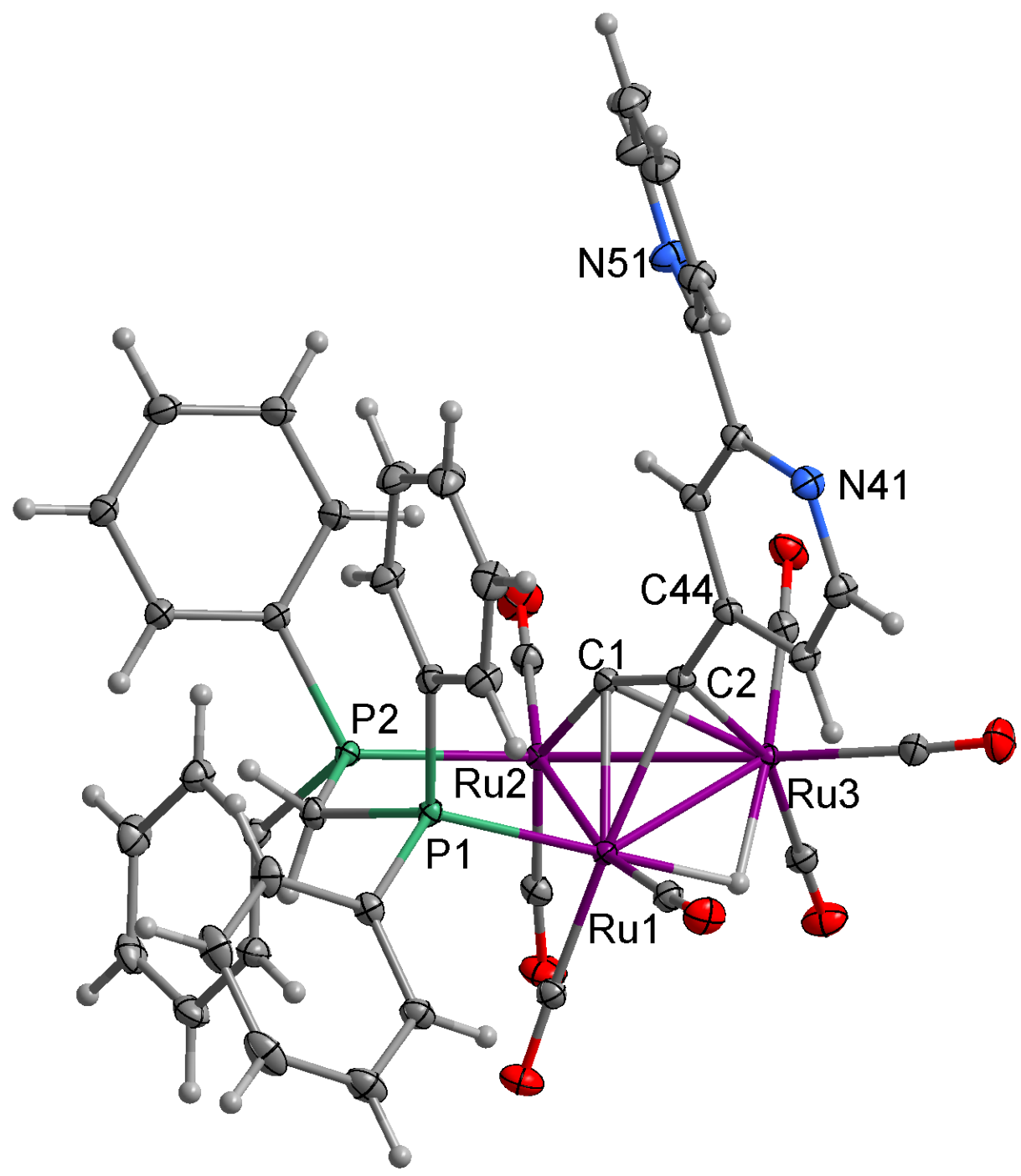

Figure 1. A plot of a molecule of $\mathbf{4}$ showing the atom labelling scheme with atomic displacement ellipsoids shown at the $50 \%$ probability level. In this and all subsequent Figures, hydrogen atoms are shown as spheres with an arbitrary radius. 


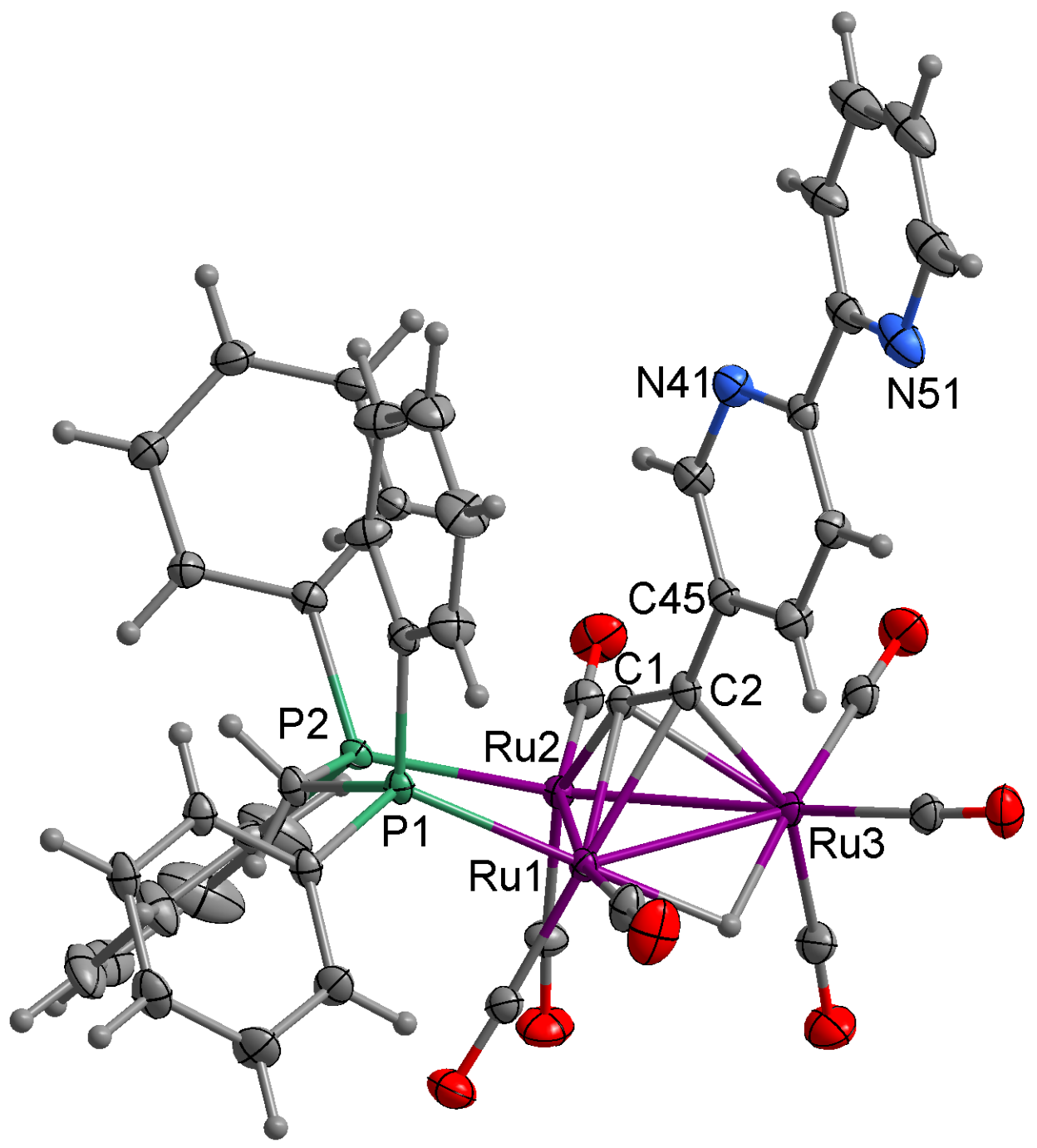

Figure 2. A plot of a molecule of $\mathbf{5}$ showing the atom labelling scheme. Atomic displacement ellipsoids are plotted at the $50 \%$ probability level. 


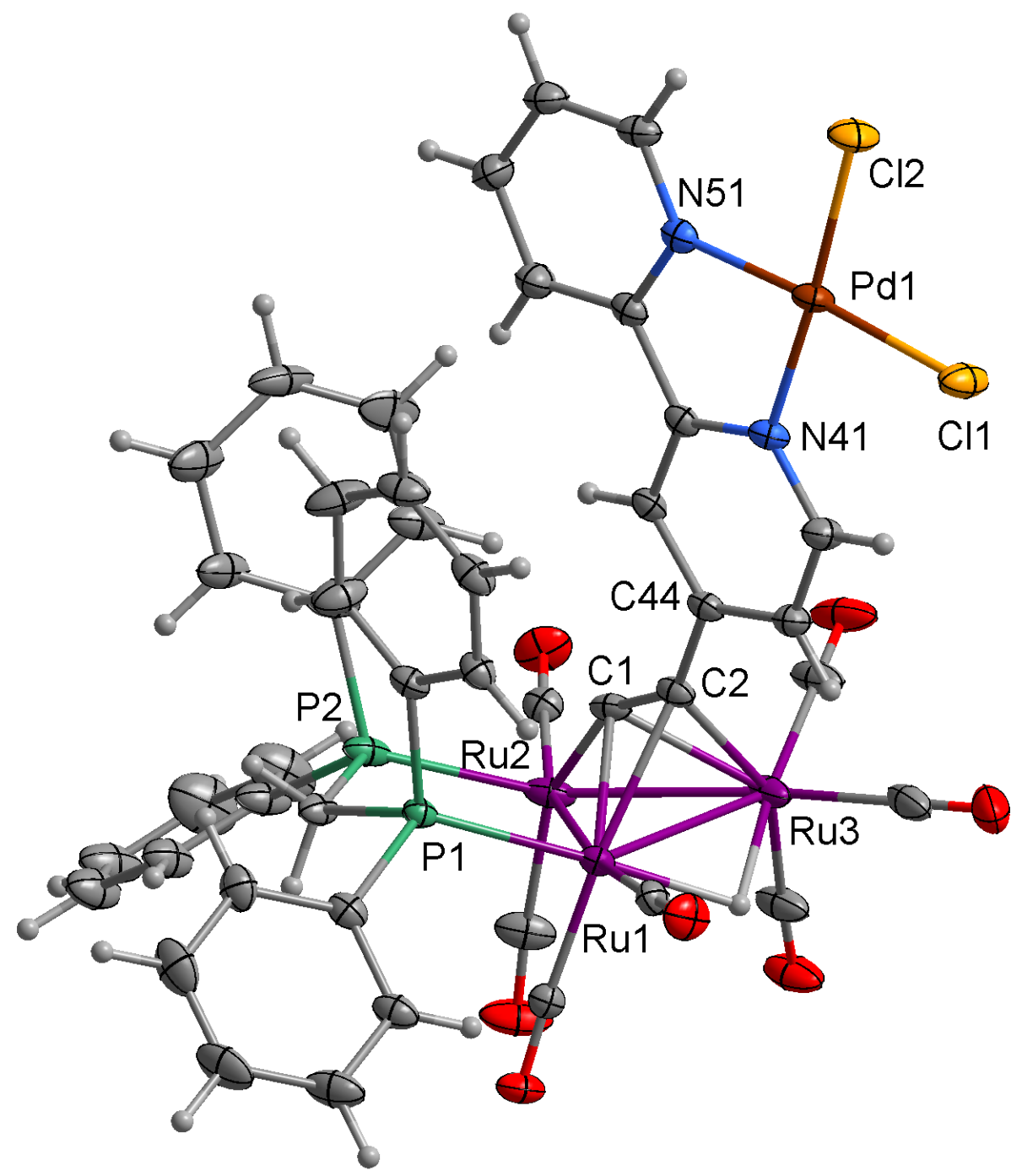

Figure 3. A plot of a molecule of $\mathbf{6}$ showing the atom labelling scheme. Atomic displacement ellipsoids are plotted at the $30 \%$ probability level. 


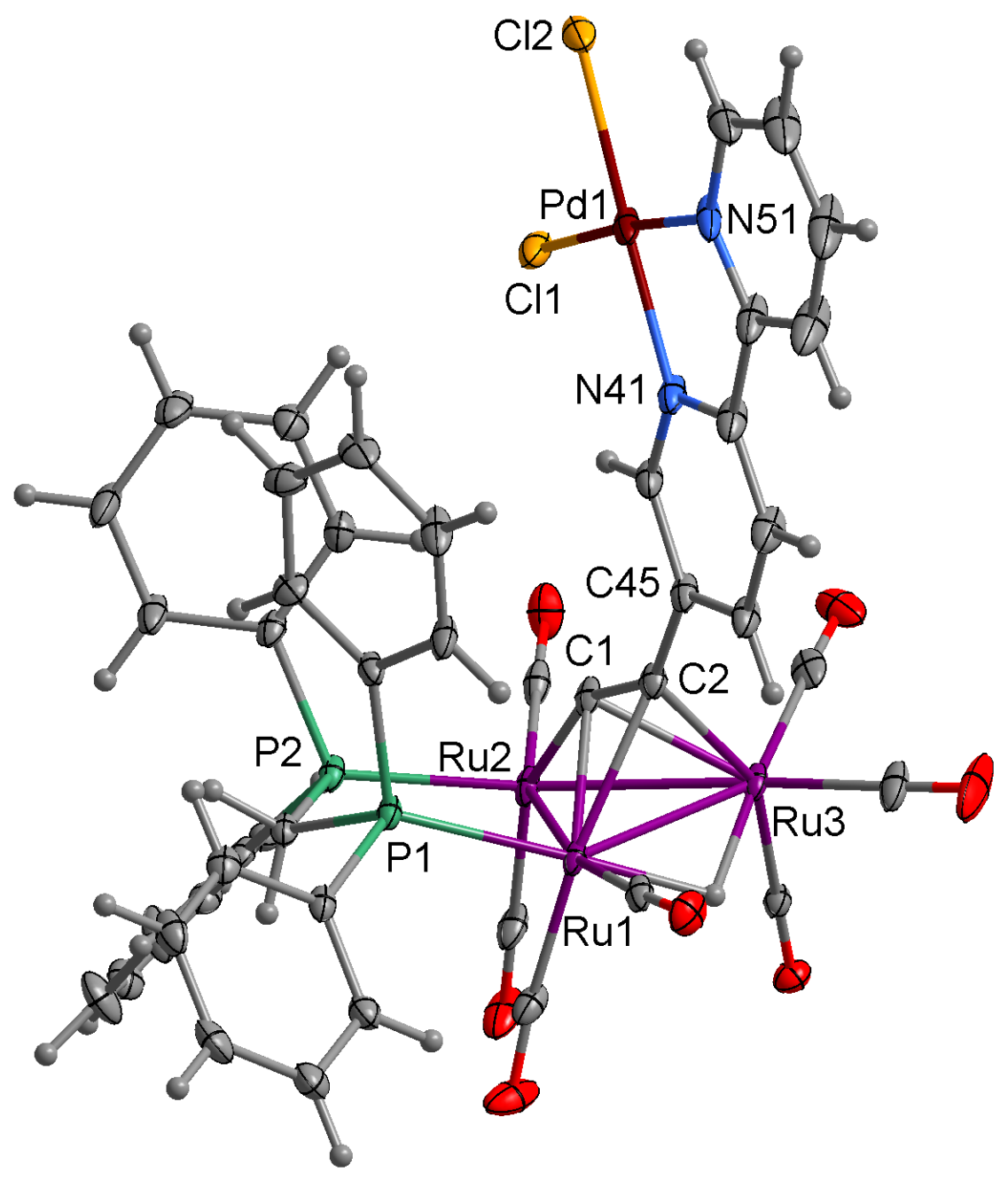

Figure 4. A plot of a molecule of 7 showing the atom labelling scheme. Atomic displacement ellipsoids are plotted at the $30 \%$ probability level.

Inspection of the structures reveals few significant differences in the cluster geometries within the family of compounds $4,5,6$ and 7 . The metal core adopts a close to equilateral triangular geometry in $\mathbf{4}$, although the hydride-bridged $\mathrm{Ru}(1)$ $\mathrm{Ru}(3)$ bond is somewhat shorter in the case of 5, 6 and 7. The hydride was identified in the difference maps, and refined in all cases, although other hydrogen atoms were placed in calculated positions and refined in a riding model. The 2,2'-bipyridyl fragment is distinctly non-planar in $\mathbf{4}$, and also in $\mathbf{5}$ albeit to a lesser degree (Table 1). 
Coordination of the $\mathrm{PdCl}_{2}$ fragment gives rise to the anticipated planarization of the 2,2'-bipyridyl moiety. However, in the case of the 4-substituted 2,2'-bipyridiyl heterometallic complex 6, the trend in $\mathrm{Ru}(2)-\mathrm{C}(1), \mathrm{C}(1)-\mathrm{C}(2), \mathrm{C}(2)-\mathrm{C}(44)$ and $\mathrm{Pd}-$ $\mathrm{N}(41)$ bond lengths in comparison with those in the 5-ethynyl isomer 7 suggests a degree of donor-acceptor character between the cluster and Pd fragments through the linearly conjugated 4-substituted 2,2'-bipyridyl fragment. This is supported by the small shift in cluster $v(\mathrm{CO})$ frequencies to higher wavenumbers through the series $\mathbf{5} \approx \mathbf{4}<\mathbf{7}<\mathbf{6}$. It is also of note that in the case of $\mathbf{6}$ the steric requirements of the 4 ethynyl bipyridyl moiety causes the $\mathrm{PdCl}_{2}$ fragment to reside "exo" of the $\mathrm{Ru}_{3}$ triangle while in 7 the $\mathrm{PdCl}_{2}$ unit points towards the $\mathrm{Ru}_{3}$. The phenomena no doubt consequent of packing preference in the solid state. 
Table 1. Selected bond lengths $(\AA)$, bond and torsion angles $\left(^{(}\right)$for complexes $\mathbf{4 , 5}, \mathbf{6}$ and 7.

\begin{tabular}{|c|c|c|c|c|}
\hline & 4 & 5 & 6 & 7 \\
\hline $\mathrm{Ru}(1)-\mathrm{Ru}(2)$ & $2.8077(4)$ & $2.82559(14)$ & $2.8163(6)$ & $2.8015(5)$ \\
\hline $\mathrm{Ru}(1)-\mathrm{Ru}(3)$ & $2.7935(5)$ & $2.7888(5)$ & $2.7767(6)$ & $2.7726(5)$ \\
\hline $\mathrm{Ru}(2)-\mathrm{Ru}(3)$ & $2.7929(6)$ & $2.82783(15)$ & $2.8118(8)$ & $2.8337(5)$ \\
\hline $\mathrm{Ru}(1)-\mathrm{P}(1)$ & $2.2990(3)$ & $2.2954(4)$ & $2.3084(14)$ & $2.3190(11)$ \\
\hline $\mathrm{Ru}(2)-\mathrm{P}(2)$ & $2.2883(3)$ & $2.2908(4)$ & $2.2735(18)$ & $2.2873(11)$ \\
\hline $\mathrm{Ru}(2)-\mathrm{C}(1)$ & $1.9527(11)$ & $1.9358(13)$ & $1.925(6)$ & $1.937(4)$ \\
\hline$C(1)-C(2)$ & $1.3201(15)$ & $1.3218(18)$ & $1.326(8)$ & $1.318(6)$ \\
\hline$C(2)-C(44) /(45)$ & $1.4587(15)$ & $1.4549(19)$ & $1.445(7)$ & $1.456(6)$ \\
\hline $\mathrm{Pd}-\mathrm{N}(41)$ & & & $2.018(4)$ & $2.026(4)$ \\
\hline $\mathrm{Pd}-\mathrm{N}(51)$ & & & $2.028(5)$ & $2.031(4)$ \\
\hline $\mathrm{Pd}-\mathrm{Cl}(1)$ & & & $2.2891(16)$ & $2.2996(14)$ \\
\hline $\mathrm{Pd}-\mathrm{Cl}(2)$ & & & $2.2748(14)$ & $2.2883(14)$ \\
\hline $\mathrm{Ru}(1)-\mathrm{Ru}(2)-\mathrm{Ru}(3)$ & $59.841(3)$ & $60.481(4)$ & $59.12(2)$ & $58.94(1)$ \\
\hline $\mathrm{Ru}(2)-\mathrm{Ru}(3)-\mathrm{Ru}(1)$ & $60.342(3)$ & $60.401(4)$ & $60.52(2)$ & $59.95(1)$ \\
\hline $\mathrm{Ru}(3)-\mathrm{Ru}(1)-\mathrm{Ru}(2)$ & $59.816(3)$ & $60.481(4)$ & $60.36(2)$ & $61.11(1)$ \\
\hline $\mathrm{Ru}(2)-\mathrm{C}(1)-\mathrm{C}(2)$ & $150.61(9)$ & $153.9(1)$ & $154.2(4)$ & $153.9(4)$ \\
\hline $\mathrm{C}(1)-\mathrm{C}(2)-\mathrm{C}(44) /(45)$ & $144.8(1)$ & $139.7(1)$ & $140.6(5)$ & $141.3(4)$ \\
\hline $\mathrm{N}(41)-\mathrm{C}(42)-\mathrm{C}(52)-$ & 153.73 & 171.52 & 3.86 & -0.06 \\
\hline $\mathrm{N}(51)$ & & & & \\
\hline
\end{tabular}




\section{Conclusion}

The 4-ethynyl and 5-ethynyl-derivatives of 2,2'-bipyridine react readily with $\left[\mathrm{Ru}_{3}(\mathrm{CO})_{10}(\mathrm{dppm})\right]$ under mild thermally activated conditions to give the anticipated electron precise $48 \mathrm{CVE}$ hydrido clusters, $\left[\mathrm{Ru}_{3}(\mu-\mathrm{H})\left(\mu-\mathrm{C}_{2}\right.\right.$ bpy $\left.)(\mathrm{CO})_{7}(\mathrm{dppm})\right]$ in moderate yield. The bipyridyl moiety is not hampered by coordination of the ethynyl pendant to the cluster, and remains available for further reaction, allowing use as a cluster-based ligand and compatible with the 'Tinkertoy' approach to the assembly of larger structures. There is evidence for a slightly greater degree of charge transfer from the cluster to the $\mathrm{PdCl}_{2}$ (bpy) fragment through the 4-substituted bipyridyl unit.

\section{Experimental}

\subsection{General conditions}

The compounds $\mathrm{Ru}_{3}(\mathrm{CO})_{10}(\mathrm{dppm})$ [39], 4-ethynyl-2,2'-bipyridine [40-43] 5-ethynyl2,2'-bipyridine [41] and $\mathrm{PdCl}_{2}(\mathrm{NCPh})_{2}$ [44] were synthesised following literature procedures. All reaction solvents were used dried from an Innovative Technology solvent purification system. All reagents were used as purchased. Reactions were performed under inert nitrogen atmosphere. No special precautions were taken to exclude air or moisture during work up.

NMR spectra were recorded on Bruker Avance III HD 600MHz or $500 \mathrm{MHz}$ NMR spectrometers as solutions in $\mathrm{CDCl}_{3} .{ }^{1} \mathrm{H}-\mathrm{NMR}$ spectra were referenced to the residual signals of protio-chloroform set to $7.26 \mathrm{ppm}[45]$, and ${ }^{31} \mathrm{P}\left\{{ }^{1} \mathrm{H}\right\}$ NMR spectra referenced against external $\mathrm{H}_{3} \mathrm{PO}_{4}$. Comment: Although the ${ }^{31} \mathrm{P}-\mathrm{NMR}$ spectra were 
recorded proton decoupled the second phosphorus signal displayed a splitting pattern showing proton coupling caused by the hydride proton in the cluster ( $\left.\delta_{H} c a-19 \mathrm{ppm}\right)$, which fell out of the range of the decoupler. IR spectra were recorded on a Nicolet Avatar $350 \mathrm{FT}-\mathrm{IR}$ spectrometer as solutions in $\mathrm{CH}_{2} \mathrm{Cl}_{2}$. Electrospray mass spectra (ES-MS) were recorded in positive ion mode from solutions in NCMe on a Waters LCT spectrometer. Elemental analyses were performed by London Metropolitan University, London, United Kingdom.

\subsection{Syntheses}

4.2.1 Reaction of $\mathrm{Ru}_{3}(\mathrm{CO})_{10}(\mathrm{dppm})$ with 4-ethynyl-2,2'-bipyridine: Synthesis of 4 A solution of $\mathrm{Ru}_{3}(\mathrm{CO})_{10}(\mathrm{dppm})(\mathbf{1})(200 \mathrm{mg}, 0.21 \mathrm{mmol})$ and 4-ethynyl-2,2'bipyridine (2) (56 mg, $0.31 \mathrm{mmol})$ in dry THF $(20 \mathrm{ml})$ was heated at reflux point. The progress of the reaction was followed by IR spectroscopy. After 3 hours the $v(C O)$ band of $\mathbf{1}$ at $2082 \mathrm{~cm}^{-1}$ had disappeared completely, showing the complete conversion of the starting material. The solvent was removed under reduced pressure and the brown residue purified by column chromatography (silica, acetone : hexane 1:3) giving 4 as a yellow powder (49 mg, $22 \%$ ). Crystals suitable for X-ray spectroscopy could be obtained by slow diffusion of $\mathrm{MeOH}$ into a $\mathrm{CH}_{2} \mathrm{Cl}_{2}$ solution of the compound. ${ }^{1} \mathrm{H}-\mathrm{NMR}\left(\mathrm{CDCl}_{3}, 600 \mathrm{MHz}\right) \delta / \mathrm{ppm}: 8.74\left(1 \mathrm{H}, \mathrm{d}, J=4.2 \mathrm{~Hz}, \mathrm{H}^{6}\right), 8.46$ $\left(1 \mathrm{H}, \mathrm{d}, J=5.0 \mathrm{~Hz}, \mathrm{H}^{6}\right), 8.33\left(1 \mathrm{H}, \mathrm{d}, J=7.8 \mathrm{~Hz}, \mathrm{H}^{3}\right), 8.16\left(1 \mathrm{H}, \mathrm{s}, \mathrm{H}^{3}\right), 8.05-8.00$ $\left(2 \mathrm{H}, \mathrm{m}, \mathrm{Ph}^{\mathrm{D}}\right), 7.82\left(1 \mathrm{H}\right.$, pseudo-t, $\left.J=7.8 \mathrm{~Hz}, \mathrm{H}^{4}\right), 7.66-7.61\left(2 \mathrm{H}, \mathrm{m}, \mathrm{Ph}^{\mathrm{C}}\right), 7.59-$ $7.53\left(3 \mathrm{H}, \mathrm{m}, \mathrm{Ph}^{\mathrm{D}}\right), 7.52-7.44\left(3 \mathrm{H}, \mathrm{m}, \mathrm{Ph}^{\mathrm{C}}\right), 7.39-7.30\left(6 \mathrm{H}, \mathrm{m}, \mathrm{Ph}^{\mathrm{B}}\right.$ and $\left.\mathrm{H}^{5}\right), 7.16$ $\left(1 \mathrm{H}, \mathrm{d}, J=5.0 \mathrm{~Hz}, \mathrm{H}^{5}\right), 6.52\left(1 \mathrm{H}, \mathrm{t}, J=6.8 \mathrm{~Hz}, \mathrm{Ph}^{\mathrm{A}}\right), 6.39-6.34\left(2 \mathrm{H}, \mathrm{m}, \mathrm{Ph}^{\mathrm{A}}\right), 6.34-$ $6.28\left(2 \mathrm{H}, \mathrm{m}, \mathrm{Ph}^{\mathrm{A}}\right), 4.32-4.21\left(1 \mathrm{H}, \mathrm{m}, \mathrm{CH}_{2}\right), 3.32-3.21\left(1 \mathrm{H}, \mathrm{m}, \mathrm{CH}_{2}\right),-19.38(1 \mathrm{H}$, $\mathrm{d}, J=33.7 \mathrm{~Hz}, \mu-\mathrm{H}) .{ }^{31} \mathrm{P}-\mathrm{NMR}\left(\mathrm{CDCl}_{3}, 202 \mathrm{MHz}\right) \delta / \mathrm{ppm}: 38.44(\mathrm{~d}, J=52.2 \mathrm{~Hz})$, 
$34.39(\mathrm{dd}, J=52.2,27.2 \mathrm{~Hz})$. IR $\left(\mathrm{CH}_{2} \mathrm{Cl}_{2}\right) \vee / \mathrm{cm}^{-1}: 2065$ (s), 2007 (s), 2001 (s), 1980 (m), 1954 (m), 1931 (w). ES(+)-MS m/z: $1066[\mathrm{M}+\mathrm{H}]^{+}, 1129[\mathrm{M}+\mathrm{Na}+\mathrm{MeCN}]^{+}$. Elemental analysis: calculated for $\mathrm{C}_{44} \mathrm{H}_{30} \mathrm{~N}_{2} \mathrm{O}_{7} \mathrm{P}_{2} \mathrm{Ru}_{3}$ : C: 49.35, H: $3.48 \%$, N: $2.62 \%$; found: C: 49.34, H: $3.39 \%, \mathrm{~N}: 2.67 \%$

\subsubsection{Reaction of $\mathrm{Ru}_{3}(\mathrm{CO})_{10}(\mathrm{dppm})$ with 5-ethynyl-2,2'-bipyridine: Synthesis of 5} Compound 5 was isolated (122 mg, 55\%) in a manner entirely analogous to that described for 4 from $\mathrm{Ru}_{3}(\mathrm{CO})_{10}(\mathrm{dppm})$ (1) (200 mg, $\left.0.21 \mathrm{mmol}\right)$ and 5-ethynyl-2,2'bipyridine (3) (56 mg, $0.31 \mathrm{mmol}$ ). Crystals suitable for X-ray diffraction were grown by slow diffusion $\left(\mathrm{CH}_{2} \mathrm{Cl}_{2} / \mathrm{MeOH}\right) .{ }^{1} \mathrm{H}-\mathrm{NMR}\left(\mathrm{CDCl}_{3}, 600 \mathrm{MHz}\right) \delta / \mathrm{ppm}$ : $8.69(1 \mathrm{H}$, pseudo-d, $\left.J=4.8 \mathrm{~Hz}, \mathrm{H}^{6}\right), 8.46\left(1 \mathrm{H}, \mathrm{d}, J=2.0 \mathrm{~Hz}, \mathrm{H}^{6}\right), 8.37(1 \mathrm{H}$, pseudo-d, $J=7.7$ $\left.\mathrm{Hz}, \mathrm{H}^{3}\right), 8.21\left(1 \mathrm{H}, \mathrm{d}, J=8.2 \mathrm{~Hz}, \mathrm{H}^{3}\right), 8.03-7.93\left(2 \mathrm{H}, \mathrm{m}, \mathrm{Ph}^{\mathrm{B}}\right), 7.82(1 \mathrm{H}$, pseudo-t, $J$ $\left.=7.7 \mathrm{~Hz}, \mathrm{H}^{4}\right), 7.66\left(1 \mathrm{H}, \mathrm{dd}, J=8.2,2.0 \mathrm{~Hz}, \mathrm{H}^{4}\right), 7.65-7.58\left(2 \mathrm{H}, \mathrm{m}, \mathrm{Ph}^{\mathrm{B}}\right), 7.56-$ $7.41\left(6 \mathrm{H}, \mathrm{m}, \mathrm{Ph}^{\mathrm{B}}(1 \mathrm{H})\right.$ and $\left.\mathrm{Ph}^{\mathrm{C}}(5 \mathrm{H})\right), 7.41-7.33\left(5 \mathrm{H}, \mathrm{m}, \mathrm{Ph}^{\mathrm{D}}\right), 7.31(1 \mathrm{H}, \mathrm{dd}, J=7.7$, $\left.4.8 \mathrm{~Hz}, \mathrm{H}^{5}\right), 6.92-6.83\left(1 \mathrm{H}, \mathrm{m}, \mathrm{Ph}^{\mathrm{A}}\right), 6.51-6.43\left(2 \mathrm{H}, \mathrm{m}, \mathrm{Ph}^{\mathrm{A}}\right), 6.41-6.31(2 \mathrm{H}, \mathrm{m}$, $\left.\mathrm{Ph}^{\mathrm{A}}\right), 4.35-4.26\left(1 \mathrm{H}, \mathrm{m}, \mathrm{CH}_{2}\right), 3.35-3.27\left(1 \mathrm{H}, \mathrm{m}, \mathrm{CH}_{2}\right),-19.27(1 \mathrm{H}, \mathrm{d}, J=33.3$ $\mathrm{Hz}, \mu-\mathrm{H}) .{ }^{31} \mathrm{P}-\mathrm{NMR}\left(\mathrm{CDCl}_{3}, 202 \mathrm{MHz}\right) \delta / \mathrm{ppm}: 38.44(\mathrm{~d}, J=52.2 \mathrm{~Hz}), 34.39(\mathrm{dd}, J$ $=52.2,27.2 \mathrm{~Hz}) . \mathrm{IR}\left(\mathrm{CH}_{2} \mathrm{Cl}_{2}\right) v / \mathrm{cm}^{-1}: 2064(\mathrm{~s}), 2004(\mathrm{~s}), 2000(\mathrm{~s}), 1978(\mathrm{~m}), 1953$ (m), 1930 (w).ES-(+)-MS m/z: $1066[\mathrm{M}+\mathrm{H}]^{+}, 1129[\mathrm{M}+\mathrm{Na}+\mathrm{MeCN}]^{+}$. Elemental analysis: calculated for $\mathrm{C}_{44} \mathrm{H}_{30} \mathrm{~N}_{2} \mathrm{O}_{7} \mathrm{P}_{2} \mathrm{Ru}_{3}$ : C: 49.35, H: $3.48 \%$, N: $2.62 \%$; found: $\mathrm{C}$ : 49.35, H: $3.42 \%, \mathrm{~N}: 2.71 \%$.

\subsubsection{Reaction of 4 with $\mathrm{PdCl}_{2}(\mathrm{NCPh})_{2}$ : Synthesis of $\mathbf{6}$.}

To a solution of 4 (43 mg, $0.04 \mathrm{mmol})$ in dry THF (3 ml), $\mathrm{PdCl}_{2}\left(\mathrm{NCPh}_{2}(16 \mathrm{mg}, 0.04\right.$ mmol) was added, resulting in a colour change from yellow to orange-red. After 
stirring for 5 minutes, the solution was concentrated under reduced pressure to approx. $2 \mathrm{ml}$. Hexanes $(10 \mathrm{ml})$ were added to precipitate the product as orange powder. The precipitate was collected by filtration, washed with hexanes $(5 \mathrm{ml})$ and dried in air. The product was further purified by recrystallisation from $\mathrm{CH}_{2} \mathrm{Cl}_{2} / \mathrm{MeOH}$ by slow diffusion ( $23 \mathrm{mg}, 55 \%$ ). Crystals suitable for X-ray were obtained by slow diffusion $\left(\mathrm{CHCl}_{3} / \mathrm{MeOH}\right) .{ }^{1} \mathrm{H}-\mathrm{NMR}\left(\mathrm{CDCl}_{3}, 500 \mathrm{MHz}\right) \delta / \mathrm{ppm}: 9.49(1 \mathrm{H}, \mathrm{dd}, J=$ 5.7, $\left.1.0 \mathrm{~Hz}, \mathrm{H}^{6^{\prime}}\right), 8.81\left(1 \mathrm{H}, \mathrm{d}, J=6.0 \mathrm{~Hz}, \mathrm{H}^{6}\right), 8.09\left(1 \mathrm{H}\right.$, pseudo-t, $\left.J=7.8 \mathrm{~Hz}, \mathrm{H}^{4}\right)$, $8.07-8.02(2 \mathrm{H}, \mathrm{m}, \mathrm{Ph}), 7.73\left(1 \mathrm{H}, \mathrm{d}, J=7.8 \mathrm{~Hz}, \mathrm{H}^{3}\right), 7.72-7.67(1 \mathrm{H}, \mathrm{m}, \mathrm{Ph}), 7.65-$ $7.45\left(6 \mathrm{H}, \mathrm{m}, \mathrm{H}^{3}\right.$ and $\left.\mathrm{Ph}\right), 7.53-7.45(3 \mathrm{H}, \mathrm{m}, \mathrm{Ph}), 7.45-7.35$ (5H, m, Ph), $7.00(1 \mathrm{H}$, $\left.\mathrm{dd}, J=7.8,5.7 \mathrm{~Hz}, \mathrm{H}^{5}\right), 6.96\left(1 \mathrm{H}, \mathrm{dd}, J=6.0,1.8 \mathrm{~Hz}, \mathrm{H}^{5}\right), 6.63-6.57(2 \mathrm{H}, \mathrm{m}, \mathrm{Ph})$, $6.24(2 \mathrm{H}, \mathrm{dd}, J=12.1,7.6 \mathrm{~Hz}, \mathrm{Ph}), 4.29-4.20\left(1 \mathrm{H}, \mathrm{m}, \mathrm{CH}_{2}\right), 3.32-3.22(1 \mathrm{H}, \mathrm{m}$, $\left.\mathrm{CH}_{2}\right),-19.36(1 \mathrm{H}, \mathrm{d}, J=33.6 \mathrm{~Hz}, \mu-\mathrm{H}) .{ }^{31} \mathrm{P}-\mathrm{NMR}\left(\mathrm{CDCl}_{3}, 202 \mathrm{MHz}\right) \delta / \mathrm{ppm}: 37.09$ (d, $J=50.2 \mathrm{~Hz}), 36.69$ (dd, $J=50.2,22.4 \mathrm{~Hz}) . \mathrm{IR}\left(\mathrm{CH}_{2} \mathrm{Cl}_{2}\right) v / \mathrm{cm}^{-1}: 2069$ (s), 2014 (s), 2006 (s), $1986(\mathrm{~m}), 1960$ (m), 1939 (w). ES(+)-MS m/z: $1282[\mathrm{M}+\mathrm{MeCN}]^{+}, 1306$ $[\mathrm{M}+\mathrm{H}+\mathrm{Na}+\mathrm{MeCN}]^{+}$. Elemental analysis: calculated for $\mathrm{C}_{44} \mathrm{H}_{30} \mathrm{~N}_{2} \mathrm{Cl}_{2} \mathrm{O}_{7} \mathrm{P}_{2} \mathrm{PdRu}_{3}$ : C:42.58, H: $2.44 \%$, N: $2.26 \%$; calculated for $\mathrm{C}_{44} \mathrm{H}_{30} \mathrm{~N}_{2} \mathrm{Cl}_{2} \mathrm{O}_{7} \mathrm{P}_{2} \mathrm{PdRu}_{3} \cdot \mathrm{CH}_{2} \mathrm{Cl}_{2}$. $\mathrm{CH}_{3} \mathrm{OH}: \quad \mathrm{C}: 39.67, \mathrm{H}: 2.53 \%$, N: $2.01 \%$; found: $\mathrm{C}: 39.59, \mathrm{H}: 2.35 \%, \mathrm{~N}: 2.26 \%$

\subsubsection{Reaction of 5 with $\mathrm{PdCl}_{2}(\mathrm{NCPh})_{2}$ : Synthesis of 7}

The reaction of $5(122 \mathrm{mg}, 0.11 \mathrm{mmol})$ with $\mathrm{PdCl}_{2}(\mathrm{NCPh})_{2}(44 \mathrm{mg}, 0.11 \mathrm{mmol})$ in dry THF ( $7 \mathrm{ml}$ ) was carried out as described above for 4 , and the product purified by precipitation (hexanes) and recrystallization $\left(\mathrm{CH}_{2} \mathrm{Cl}_{2} /\right.$ hexanes) to give 7 (41 $\mathrm{mg}, 35$ \%). ${ }^{1} \mathrm{H}-\mathrm{NMR}\left(\mathrm{CDCl}_{3}, 500 \mathrm{MHz}\right) \delta / \mathrm{ppm}: 9.49\left(1 \mathrm{H}, \mathrm{d}, J=5.6 \mathrm{~Hz}, \mathrm{H}^{6}\right), 8.85(1 \mathrm{H}, \mathrm{d}$, $\left.J=1.6 \mathrm{~Hz}, \mathrm{H}^{6}\right), 8.09\left(1 \mathrm{H}\right.$, pseudo-t, $\left.J=7.6 \mathrm{~Hz}, \mathrm{H}^{4}\right), 7.97(2 \mathrm{H}, \mathrm{m}), 7.89(1 \mathrm{H}, \mathrm{d}, J=$ $\left.7.6 \mathrm{~Hz}, \mathrm{H}^{3}\right), 7.86\left(1 \mathrm{H}\right.$, pseudo-d, $\left.J=8.0 \mathrm{~Hz}, \mathrm{H}^{4}\right), 7.79-7.73(3 \mathrm{H}, \mathrm{m}), 7.66-7.61$ 
(1H, pseudo-t, $J=6.8 \mathrm{~Hz}), 7.60-7.54\left(3 \mathrm{H}\right.$, pseudo-t, $J=7.5 \mathrm{~Hz}, \mathrm{H}^{5^{\prime}}$ and $\left.\mathrm{Ph}\right), 7.50-$ $7.33(9 \mathrm{H}, \mathrm{m}), 6.76(2 \mathrm{H}, \mathrm{t}, J=7.1 \mathrm{~Hz}), 6.29-6.22(2 \mathrm{H}, \mathrm{m}), 4.26-4.15\left(1 \mathrm{H}, \mathrm{m}, \mathrm{CH}_{2}\right)$, $3.35-3.23\left(1 \mathrm{H}, \mathrm{m}, \mathrm{CH}_{2}\right),-19.31(1 \mathrm{H}, \mathrm{d}, J=31.7 \mathrm{~Hz}, \mu-\mathrm{H}) .{ }^{31} \mathrm{P}-\mathrm{NMR}\left(\mathrm{CDCl}_{3}, 202\right.$ MHz) $\delta /$ ppm: $38.28(\mathrm{~d}, J=49.6 \mathrm{~Hz}), 36.13(\mathrm{dd}, J=49.5,29.2 \mathrm{~Hz}) . \mathrm{IR}\left(\mathrm{CH}_{2} \mathrm{Cl}_{2}\right) v /$ $\mathrm{cm}^{-1}: 2067$ (s), 2011 (s), 2003 (s), 1984 (m), 1958 (m), 1937 (w).ES(+)-MSm/z: 1282 $[\mathrm{M}+\mathrm{MeCN}]^{+}, 1306[\mathrm{M}+\mathrm{H}+\mathrm{Na}+\mathrm{MeCN}]^{+}$

\subsection{Crystallography}

The crystal data for $\mathbf{4}, \mathbf{5}, \mathbf{6}$ and $\mathbf{7}$ are summarized in Table 2 with the structures depicted in Figs. 1-4. Selected bond lengths and bond and torsion angles are listed in Table 1. Crystallographic data for the structures were collected at 100(2) K on an Oxford Diffraction Xcalibur diffractometer fitted with $\operatorname{MoK\alpha }(\mathbf{4}, \mathbf{5}, \mathbf{7})$ or an Oxford Diffraction Gemini diffractometer fitted with $\mathrm{CuK \alpha (6)}$ radiation. Following analytical absorption corrections and solution by direct methods, the structures were refined against $F^{2}$ with full-matrix least-squares using the program SHELXL-2014 [46] The hydrido atom was refined without restraints in 4, 5 and 6. All remaining hydrogen atoms were added at calculated positions and refined by use of a riding model with isotropic displacement parameters based on those of the parent atoms. All nonhydrogen atoms were refined with anisotropic displacement parameters.

In the case of $\mathbf{6}$, a sample was recrystallised from $\mathrm{CH}_{2} \mathrm{Cl}_{2} / \mathrm{MeOH}$ but the crystals were of poor quality. The structure reported here was the result of recrystallisation from $\mathrm{CHCl}_{3} / \mathrm{MeOH}$. The first crystal chosen contained $\mathrm{CHCl}_{3}$ as the only solvent but was twinned. The presented structure was from a second crystal from the same sample and 
contains both $\mathrm{CHCl}_{3}$ and $\mathrm{MeOH}$. The $\mathrm{CHCl}_{3}$ and the $\mathrm{CHCl}_{3} / \mathrm{MeOH}$ solvates have similar triclinic cells. In the presented structure, the solvent was modelled as one molecule of $\mathrm{CHCl}_{3}$ and one of methanol. The geometries of the $\mathrm{CHCl}_{3}$ molecule were restrained to ideal values. Any further electron density was effectively removed using the program SQUEEZE. One carbonyl ligand $\mathrm{C}, \mathrm{O}(22)$ was modelled as being disordered over two sets sites with occupancies constrained to 0.5 . The hydrido atom was refined without restraints. All remaining hydrogen atoms were added at calculated positions and refined by use of a riding model with isotropic displacement parameters based on those of the parent atoms. All non-hydrogen atoms were refined with anisotropic displacement parameters.

In the case of 7 , the solvent modelled as two $\mathrm{CH}_{2} \mathrm{Cl}_{2}$ molecules both of which are disordered over two sites with occupancies constrained to 0.5 after trial refinement. The hydrido atom was refined with $\mathrm{Ru}-\mathrm{H}$ distances restrained to ideal values. All remaining hydrogen atoms were added at calculated positions and refined by use of a riding model with isotropic displacement parameters based on those of the parent atoms. All non-hydrogen atoms were refined with anisotropic displacement parameters.

Structural data have been deposited in the CCDC (1415608-1415611). These data can be obtained free of charge from The Cambridge Crystallographic Data Centre via www.ccdc.cam.ac.uk/data request/cif 
Table 2. Crystal data and structure refinement for 4, 5, 6 and $\mathbf{7 .}$

\begin{tabular}{|c|c|c|c|c|}
\hline Compound & 4 & 5 & 6 & 7 \\
\hline Empirical formula & $\mathrm{C}_{44} \mathrm{H}_{30} \mathrm{~N}_{2} \mathrm{O}_{7} \mathrm{P}_{2} \mathrm{Ru}_{3}$ & $\mathrm{C}_{44} \mathrm{H}_{30} \mathrm{~N}_{2} \mathrm{O}_{7} \mathrm{P}_{2} \mathrm{Ru}_{3}$ & $\mathrm{C}_{46} \mathrm{H}_{35} \mathrm{Cl}_{5} \mathrm{~N}_{2} \mathrm{O}_{8} \mathrm{P}_{2} \mathrm{PdRu}_{3}$ & $\mathrm{C}_{4} \mathrm{H}_{34} \mathrm{Cl}_{6} \mathrm{~N}_{2} \mathrm{O}_{7} \mathrm{P}_{2} \mathrm{PdRu}_{3}$ \\
\hline Formula weight & 1063.85 & 1063.85 & 1392.56 & 1411.00 \\
\hline Temperature/K & $100(2)$ & $100(2)$ & $100(2)$ & $100(2)$ \\
\hline Wavelength/Å & 0.71073 & 0.71073 & 1.54178 & 0.71073 \\
\hline Crystal system & Monoclinic & Monoclinic & Triclinic & Triclinic \\
\hline Space group & $P 2_{1} / c$ & $P 2_{1} / n$ & $P \overline{1}$ & $P \overline{1}$ \\
\hline$a / \AA$ & $13.05620(10)$ & $16.3113(2)$ & $11.1218(4)$ & $9.9099(4)$ \\
\hline$b / \AA$ & $15.33750(10)$ & $13.73130(10)$ & $14.7682(4)$ & $15.1144(7)$ \\
\hline$c / \AA$ & $20.10260(10)$ & $19.8666(3)$ & $15.6751(4)$ & $18.6750(6)$ \\
\hline$\alpha /^{\circ}$ & & & $94.209(2)$ & $100.657(3)$ \\
\hline$\beta /{ }^{\circ}$ & $92.3430(10)^{\circ}$ & $112.925(2)^{\circ}$ & $97.173(3)^{\circ}$ & $103.849(3)$ \\
\hline$\gamma /{ }^{\circ}$ & & & $92.499(3)^{\circ}$ & $107.364(4)$ \\
\hline$V / \AA^{3}$ & $4022.17(5)$ & $4098.18(10)$ & $2543.95(13) \AA^{3}$ & $2490.93(18)$ \\
\hline$Z$ & 4 & 4 & 2 & 2 \\
\hline$D_{\mathrm{c}} / \mathrm{Mg} \mathrm{m}^{-3}$ & 1.757 & 1.724 & 1.818 & 1.881 \\
\hline$\mu / \mathrm{mm}^{-1}$ & 1.246 & 1.223 & 13.333 & 1.685 \\
\hline Crystal size/mm 3 & $0.36 \times 0.27 \times 0.17$ & $0.45 \times 0.23 \times 0.155$ & $0.205 \times 0.098 \times 0.028$ & $0.415 \times 0.105 \times 0.035$ \\
\hline$\theta_{\min , \max } /^{\circ}$ & $2.258,38.477$ & $2.009,37.195$ & $2.850,67.341$ & $2.115,30.024$ \\
\hline \multirow[t]{2}{*}{ Index ranges } & $-22<=\mathrm{h}<=22,-$ & $-27<=\mathrm{h}<=27,-$ & $-13<=\mathrm{h}<=13,-$ & $-13<=\mathrm{h}<=13,-$ \\
\hline & $26<=\mathrm{k}<=26,-$ & $23<=\mathrm{k}<=23,-$ & $17<=\mathrm{k}<=13,-$ & $19<=\mathrm{k}<=20,-$ \\
\hline
\end{tabular}


Data / restraints /

parameters

Goodness-of-fit on $F^{2}$

$R 1, w R 2$ indices $(I>2 \sigma(I))$

$R 1, w R 2$ indices (all data)

$\Delta \rho_{\max , \min } /$ e. $\AA^{-3}$
22213 / 0 / 527

$\begin{array}{ll}1.080 & 1.066 \\ 0.0243,0.0566 & 0.0282,0.0682 \\ 0.0293,0.0590 & 0.0361,0.0728 \\ 0.994,-0.643 & 1.373,-0.936\end{array}$

9048 / 38 / 628

1.037

$0.0449,0.1203$

$0.0506,0.1246$

$1.945,-1.802$
$13116 / 2$ / 662

1.061

$0.0511,0.0890$

$0.0786,0.0996$ 


\section{Acknowledgements}

We gratefully acknowledge the Australian Research Council for funding (DP DP140100855). P.J.L. holds an ARC Future Fellowship (FT FT120100073). holds an International Postgraduate Research Scholarship, and S.B. and C.F.I both awarded Australian Postgraduate Award and the UWA Safety Net Top-1 Scholarships by The University of Western Australia and the Australian Gov' The authors acknowledge the facilities, and the scientific and technical assist: the Australian Microscopy \& Microanalysis Research Facility at the Centre $f$ Microscopy, Characterisation \& Analysis, The University of Western Austra] facility funded by the University, State and Commonwealth Governments.

\section{References}

1. J. Lewis, P.R. Raithby, J. Organomet. Chem. 1995, 500, 227-237.

2. R.B. King, Prog. Inorg. Chem. 1972, 15, 287-473

3. F.G.A. Stone, Angew. Chem. Int. Ed. Engl. 1984, 23, 89-99.

4. M.I. Bruce, Coord. Chem. Rev. 1987, 76, 1-43.

5. Comprehensive Organometallic Chemistry II, 1995, Vol 7.Elsevier, E Abel, F.G.A. Stone, G. Wilkinson, Eds.

6. H. Lang, R. Packheiser, B. Walfort, Organometallics, 2006, 25, 1836

7. H. Lang, R. Packheiser, Coll. Czech. Chem. Commun. 2007, 72, 435-ء

8. W. Cen, K.J. Haller, T.P. Fehlner, Inorg. Chem., 1993, 32, 995-1000.

9. G.A. Koutsantonis, P.A. Schauer, B.W. Skelton, Organometallics, 20 2680-2689. 
10. M.P. Cifuentes, M.G. Humphrey, G.A. Koutsantonis, N.A. Lengkeek, S. Petrie, V. Sandord, P.A. Schauer, B.W. Skelton, R. Stranger, A.H. White, Organometallics, 2008, 27, 1716-1726.

11. G.A. Koutsantonis, G.I. Jenkins, P.A. Schauer, B. Szczepaniak, B.W. Skelton, C. Tan, A.H. White, Organometallics, 2009, 28, 2195-2205.

12. R. Packheiser, H. Lang, Eur. J. Inorg. Chem. 2007, 3786-3788.

13. R. Packheiser, H. Lang, Inorg. Chem. Commun. 2007, 10, 580-582.

14. G.A. Koutsantonis, P.J. Low, C.F.R. Mackenzie, B.W. Skelton, D.S. Yufit, Organometallics, 2014, 33, 4911-4922.

15. G. Sanchez-Cabrera, F.J. Zuno-Cruz, M.J. Rosales-Hoz, J. Cluster Sci. 2014, 25, 51-82.

16. P.R. Raithby, M.J. Rosales, Adv. Inorg. Chem. 1985, 29, 169-247.

17. J.F. Halet, Coord. Chem. Rev. 1995, 143, 637-678.

18. P.J. Low, J. Cluster Sci. 2008, 19, 5-46.

19. P.J. Low, M.I. Bruce, Adv. Organomet. Chem. 2001, 48, 71-288.

20. M.I. Bruce, P.J. Low, Adv. Organomet. Chem. 2004, 50, 179-2004.

21. G.A. Foulds, B.F.G. Johnson, J. Lewis, J. Organomet. Chem. 1985, 294, 123 129.

22. A.J. Deeming, R. Peters, M.B. Hursthouse, J.D.J. Backer-Dirks, J. Chem. Soc., Dalton Trans. 1982, 787-791.

23. T. Venäläinen, J. Pursiainen, T. A. Pakkanen, J. Chem. Soc., Chem. Commun. $1985,1348-1349$.

24. M.I. Bruce, M.G. Humphrey, M.R. Snow, E.R.T. Tiekink, R.C. Wallis, J. Organomet. Chem. 2986, 314, 311-322. 
25. M. DealVarga, R. Costa, R. Reina, A. Núñez, M.A. Maestro, J. Mahía, J. Organomet. Chem., 2003, 677, 101-117.

26. J. Nijhoff, M.J. Bakker, F. Hartl, G. Freeman, A.L. Ingham, B.F.G. Johnson, J. Chem. Soc., Dalton Trans. 1998, 2625-2633.

27. G. Freeman, S.L. Ingham, B.F.G. Johnson, M. McPartlin, I.J. Scowen, J. Chem. Soc., Dalton Trans. 1997, 2705-2711.

28. J.A. Cabeza, I. da Silva, I. del Rio, L. Martinez-Mendez, D. Miguel, V. Riera, Angew. Chem., Int. Ed. Engl. 2004, 43, 3464-3467.

29. J.A. Cabeza, I. del Rio, L. Martinez-Mendez, D. Miguel, Chem. Eur. J. 2006, 12, 1529-1538.

30. B. Poola, C.J. Carrano, M.G. Richmond, Organometallics, 2008, 27, 30183028 .

31. P.J. Low, K.A. Udachin, G.D. Enright, A.J. Carty, J. Organomet. Chem. 1999, 578, 103-114.

32. G.A. Foulds, B.F.G. Johnson, J. Lewis, J. Organomet. Chem. 1985, 296, $147-$ 153.

33. B.F.G. Johnson, J. Lewis, D.A. Pippard, J. Chem. Soc., Dalton Trans., 1981, 407-412.

34. S.R. Drake, R. Khattar, Organomet. Synth., 1988, 4, 234-237.

35. S. Rivomanana, G. Lavigne, N. Lugan, J.-J. Bonnet, Organometallics, 1991, 10, 2285-2297.

36. P.J. Low, T.M. Hayes, K.A. Udachin, A.E. Goeta, J.A.K. Howard, G.D. Enright, A.J. Carty, J. Chem. Soc., Dalton Trans. 2002, 1455-1464.

37. (a) M.I. Bruce, P.A. Humphrey, E. Horn, E.R.T. Tiekink, B.W. Skelton, A.H. White, J. Organomet.Chem. 1992, 429, 207-227. (b) L.T. Byrne, N.S. 
Hondow, G.A. Koutsantonis, B.W. Skelton, A.A. Torabi, A.H. White, S.B. Wild, J. Organomet. Chem, 2008, 693, 1738-1750. (c) A.A. Torabi, A.S. Humphreys, G.A. Koutsantonis, B.W. Skelton, A.H. White, J. Organomet. Chem., 2002, 655, 227-232. (d) S.E. Kabir, G. Hogarth, Coord. Chem. Rev.2009, 253, 1285-1315.

38. W. Henderson, B.K. Nicholson, L.J. McCaffrey, Polyhedron, 1998, 17, 42914313.

39. M. I. Bruce, B. K. Nicholson, M. L. Williams, Inorg. Synth. 1990, 28, 221230.

40. A. Baron, C. Herrero, A. Quaranta, M.-F. Charlot, W. Leibl, B. Vauzeilles, A. Aukauloo, Inorg. Chem.2012, 51, 5985-5987.

41. (a) V. Grosshenny, F. M. Romero, R. Ziessel, J. Org. Chem.1997, 62, 14911500. (b) P.F.H. Schwab, F. Fleischer, J. Michl, J. Org. Chem.2002, 67, 443449.

42. R. A. Jones, B. D. Roney, W. H. F. Sasse, K. O. Wade, J. Chem. Soc. B1967, $106-111$.

43. D. Wenkert, R. B. Woodward, J. Org. Chem.1983, 48, 283-289.

44. G. K. Anderson, M. Lin, Inorg. Synth.1990, 28, 60-63.

45. H. E. Gottlieb, V. Kotlyar, A. Nudelman, J. Org. Chem.1997, 62, 7512-7515.

46. G.M. Sheldrick, Acta Cryst. 2008, A64, 112-122. 